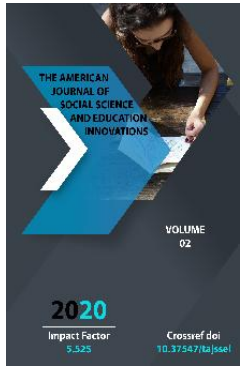

\section{Role Of Ancient Written Sources In The Formation Of The Old Uzbek Literary Language}

\author{
Nematullo Hikmatullaevich Nasrullaev \\ Candidate Of Historical Sciences, Senior Lecturer, Department Of Islamic History And Source \\ Studies IRCICA, International Islamic Academy Of Uzbekistan
}

Journal Website: http://usajournalshub.c om/index,php/tajssei

Copyright: Original content from this work may be used under the terms of the creative commons attributes 4.0 licence.

\title{
ABSTRACT
}

This article describes the role of ancient written sources in the emergence of the old Uzbek literary language. Our written heritage has an ancient and rich history, and its comprehensive study based on primary sources is more relevant today than ever. Regardless of how much the research carried out in this area to date has enriched the treasury of our linguistics, we still have a lot of work on the ancient Uzbek language and classical texts in this language.

\section{KEYWORDS}

Western Europe, Asia Minor, Central Asia and Western Siberia,Old Turkic language, Latin and Greek pronunciations.

\section{INTRODUCTION}

It is known that the first Turkic written sources began to appear in the 6th century AD. Ancient Turkic words are also found in
Chinese sources, from Iranian to Sogdian, Khorezmian and Pahlavi languages. The Uzbek language, which is one of the Turkic 
languages, has been called by different names for almost one and a half thousand years of its history. The word "Turk" is often mentioned in memoirs of the VI-VIII centuries. Judging by the content of ancient monuments, the word "Turk" originally had a political and social meaning and meant a union of tribes.

Although the Old Turkic language was reflected in the written monuments of the Blue Turkic, Uyghur, Maoni, and Brahma scripts in the VI-IX centuries, the most ancient written monuments of this language have not survived. Those that survived until the threshold of $A D$ are preserved only in the works of Greco-Roman historians with Latin and Greek pronunciations. It is therefore impossible to make any definite judgment about the phonetic and grammatical norms of the old Turkic script or language.

In ancient times, Turkic tribes lived in the area from Siberia to the Mediterranean, some settled and some nomadic. The medieval lexicographer Mahmud Kashqari writes in his Dīwān Lughāt al-Turk (Collection of Turkish Words): "In the region from the Greek border in the west to China in the east, Turkish tribes and clans are arranged in the following order: pecheneg, kipchak, oguz, yemen, bashkird, basmil, kayi, yabaku, tatar, kyrgyz, chigil, toxi, yagmo, ugrak, charuk, chomul , Uyghur, Tangut, Chinese ". In the following pages, the author also mentions the Bulgar and Suvar tribes located in the west as Turkic peoples. Ancient tombs and stone inscriptions found in these areas so far also confirm this information.

\section{MAIN PART}

This means that the Turkic peoples have lived for thousands of years under different names in Eastern and even Western Europe, Asia Minor, Central Asia and Western Siberia. Although their ethnic affiliation has not changed, at different times, as a result of the dominance of these Turkic peoples and tribes, only differences in their common names have been observed. Peter Friedrich Sum, a Danish scholar who studied the history of the Turkic peoples of Eastern Europe and Asia Minor, came to the conclusion in the 18th century: "The common name of the Turks changed frequently in connection with the victory of one tribe over another. Scythians, Sarmatians, Alans, Huns, Khazars, Uzs or Komans, Tatars are essentially common names.", admitted.

It has been 1000 years since Dīwān Lughāt alTurk was written. However, the Turkic peoples still live in the areas mentioned in this play. Now most of them have just changed their names. Of the ancient names, only Tatar, Bashkir, Kyrgyz, Uyghur and Bulgarian terms have survived. Many tribes and clans were part of modern Turkic, Azerbaijani, Uzbek, Tajik, Kazakh, Kyrgyz, Turkmen, Karakalpak and other Turkic peoples.

The Old Turkic language laid the foundation for the emergence of the old Uzbek literary language. Uzbek literary language is called "Old Uzbek language" in the linguistics of the last period of XI-XIII centuries. Especially in Central Asia, with the formation of a large centralized state of the Turkic peoples, tribes and clans - the Karakhanids (X-XII centuries), the prestige of the Turkic language increased significantly. The state center was originally Kashgar (Ordukent) and later moved to Uzgen. In the large cities under the protection of the capital, such as Shosh, Sayram, Bolosogun, Samarkand, Bukhara, the scientific and spiritual environment was much developed, and its influence even reached neighboring countries. During this period, such scholars as Mahmud Kashgari, Yusuf Khas Hajib, Ahmad Yugnaki, Ahmad Yassavi, Suleiman Bagirgani were effective. This 
marked the way for the further development of Turkish literature and literary language as the emerging traditions of written literature and literary language.

By the XIII-XIV centuries the period of the Mongol rule began in the country. Oguznoma, which, despite the difficulties of the time, reflected the heroic images in the oral tradition of the Turkic peoples, Nosiriddin Burhoniddin Rabguziy Khorezmi's large-scale "Qisasi Rabguziy" (Rabguziy stories), which narrates the traditions of ancient peoples with his stories and short stories, Sheikh Sharifi's Mu'in ul-Murid (Assistant to the Murid), Ali ibn Mahmud's Nahj ul-Farodis (Ways of Paradise), which expressed Islamic beliefs in poetry, Another written monument created in Khorezm in Uzbek and Persian-Tajik languages is Masnavi-noma, which is called "Muhabbatnoma". It is obvious that during the glorious period of the Mongols, a number of talented representatives of the Turkic language and its literature emerged.

The strengthening of the political position of the Turkic peoples, their increasing settlement, especially their active participation in the life of the city, served to further increase the prestige of the Turkic languages. As a result, the old Turkic language began to emerge from the interference of many Turkic tribes. Translating this language into a literary language that is understandable to all Turkic tribes; The written monuments of Turkic literature - manuscripts - played an important role in the study of the linguistic features of the Turkic peoples, the norms of vocabulary, the richness of vocabulary and, on this basis, the development of future ways of literary language.

The heyday of the old Uzbek literary language dates back to the XV-XVIII centuries. The works created during this period were a great turning point in the expansion of themes in terms of themes, in terms of quality, and in terms of quantity. Representatives of classical Uzbek literature, such as Haydar Khorezmi, Shaykhzoda Atoi, Mavlono Yusuf Amiri, Mavlono Lutfi, Hussein Boykaro, Alisher Navoi, Zahiriddin Muhammad Babur, Turdi Fergani, Sufi Allahyor, Munis Khorezmi and others, who lived and worked in a scientific environment, The literature and literary language of the Karakhanid period, which continued in this way, had a strong influence.

Terms of the Turkic language - "Turkish", "Turkish language", "Turkish language" are often mentioned in the works of Alisher Navoi and his contemporaries. These terms refer to the "old Uzbek language". By this time, the thematic aspect of Turkish manuscripts had expanded, their quality had increased, and their quantity had increased. This was the case under the direct patronage and leadership of Hussein Boykaro and Alisher Navoi. Personally, Alisher Navoi himself used these terms in a number of works, leaving a unique scientific and spiritual heritage for the Turkic-speaking peoples.

In particular, the work "Muhokamat ullug'atayn" (Discussion of two languages) was created in the last years of the author's life when he gained a lot of life experience, matured his scientific views, his thoughts were refined and reached the level of perfection. In his work, the author not only compares the two languages, but also compares their unique aspects and scientifically substantiates the unique features of each. In this regard, Navoi draws attention to such important aspects of the Turkic language as its unique sounds, subtle meanings, action verbs and their influence on the content, ambiguity of words, as well as the richness of the Turkic system of terms, 
which is not found in other languages, especially Persian. For example, this sentence in the work is also a proof of our word, "Bu ehtimolg'a xud yo'l bersa bo'Imaskim, turk ulusining xushtab'lari majmui sart tili bila nazm aytqoylar va bilkull turk tili bila aytmag'aylar”. Zahiriddin Muhammad Babur gives a clear but accurate assessment of Alisher Navoi's contribution to the history of the Turkic language. Babur says about Navoi's skill, weight and quality of his work: "Alisherbek naziri yo'q kishi erdi. Turkiy til bila to she'r aytubdurlar, hech kim oncha ko'b va xo'b aytqon emas"( Alisherbek was a unique man. They recited poems in Turkish, but no one recited so much).

Almost all works of Alisher Navoi were written in Uzbek. The poet's work in this language has become a constant spiritual companion not only of the Uzbeks, but of all Turkic peoples. We find his works in many copies throughout Movarounnahr, Khorasan, East Turkestan, Turkey, Iran, the Urals, the Volga region, Siberia, Azerbaijan, Crimea, India, Egypt and other countries.

Sufi Olloyar, a 17th-18th century thinker and writer, also wrote his scientific and literary work "Sabot ul-Ojizin" in Uzbek. Of course, the main goal of the author was to preserve the linguistic features of the Uzbek language, to focus on its renewal and development. That is why this work has been taught and continues to be taught from the time it was written to the present day.

Although printing of Turkic texts began in the early 19th and early 20th centuries, most of them were translations of large volumes of Arabic and Persian books into Uzbek. One of the translations of such a great work of jurisprudence was made by Rahimhoja Eshan, and the scholar translated from "Mukhtasar
ul-Viqaya" from Arabic into Uzbek by Ubaydullah ibn Mas'ud, a well-known jurist of the 14th century who received the title of "Taju-Sharia". The author followed the path of expressing this translation in verse and successfully completed it and named the book "Nazmi Mukhtasar al-Viqaya". The translation was completed in three months in 1887 and was first published in the same year. In the introduction to the work, the author, nicknamed "Khatmi", says that he started this work at the request of his Turkic-speaking friends. In particular, he states that he decided to finish this work in Turkish because of the slow development of science in Turkestan, in particular, due to the lack of resources on the science of jurisprudence.

Tangridin bizgadur ushbu ehson, Qavmi turk-u maqomi Turkiston. Garchi el beshumoru odam ko'b, Ilmu fan kamlig'i ila ma'yub.

Bas, eling turk, aylag'il turki, Turkiyg'a shod bo'Isa ul ko'rki.

Toza gul o'Isa turk elig'a bu, Zohir etsa jahona rangu bo‘.

This gift from God to us, Turkish Nation Turkestan Status. Although there are a lot of people, Disabled by lack of science.

So, your nation is Turkish, your country is Turkish,

If Turkey is happy, it is beautiful.

When a pure flower dies, it is for the Turkish people,

The innovations founded by Navoi in the creation of literary, historical and scientific works have become a tradition in Uzbek literature, science and culture in recent years. Uzbek poets and writers have made a worthy 
contribution to our spiritual heritage by creating independent works in various forms of literature. Especially in the XVII-XIX centuries, the structure of hundreds of bayoz and complexes, the translation of dozens of works from Arabic and Persian into Uzbek, the establishment of large calligraphy schools were the main factors in the growing number of manuscript sources.

In the catalogs compiled on these sources, written sources in Uzbek, Uyghur, Turkmen, Azerbaijani, Turkish, Tatar and other Turkic languages are collectively referred to as "Turkish manuscripts". They have been preserved in large numbers in the world's book treasures for centuries. Funds with a large number of Turkish manuscripts include Tashkent, Samarkand, Bukhara, Khorezm, Kokand, Dushanbe, Ashgabat, Baku, Hyderabad, Istanbul, Ankara, Delhi, Bombay, Hyderabad, Tehran, Paris, London, New York, Russia, Cairo and others, libraries in cities are now world-renowned.

\section{CONCLUSION}

The Uzbeks are one of the largest Turkic peoples, and written historical sources testify that their ancestors were the main inhabitants of the Turkestan region. Sources state that the Uzbek language belongs to the southeastern or Qarluq group of the Turkic language network of the Altaic family. According to the classification of modern Turkic scholars, currently about thirty languages in different regions of Asia and Europe belong to the network of Turkic languages. They are classified as follows:

1. In Central Asia - Uzbek, Tajik, Kazakh, Turkmen, Kyrgyz, Turkish, Karakalpak, Uyghur;

2. In the Caucasus - Azerbaijan, Kumik, Karachay-Balkar, Trukhman, Nugay;
3. Along the Urals and the Volga - Tatar, Bashkir, Mongol, Chuvash;

4. In Siberia - ruby, Tuva Altai, Khakas, Solim, Kongmaji, Tufa, Shor;

5. In Lithuania, Ukraine and Moldova Urum, Gagauz, Crimea, Karaim;

6. In Turkey and the Balkans - Turks, Kurds.

Today, some of these languages are spoken by millions of people, while others, such as Tufah and Shor in Siberia, are spoken by only 500-600 people. In general, Turkic languages are the seventh most widely spoken language in the world. According to the latest data, more than 300 million people in the world now speak Turkish.

Today, classical Turkish sources on our language and literature, such as Dīwān Lughāt al-Turk, Kutadgu Bilig (Knowledge that leads to happiness), Hibatul haqayiq (Gift of Truths), Devoni Hikmat, written in the old script until the beginning of the 2oth century. Thanks to the study of the ideological and textual basis, we have preserved the long past of our nation, fully understood the essence of their content and presented it to future generations.

So, the roots of the Uzbek language are very deep and very rich. In particular, our ancestors, who were deeply attached to the teachings, morality and education of Islam and who enjoyed its pure faith with great grace and enthusiasm, classified countless masterpieces in this way. It is no exaggeration to say that they were written in Greek, Arabic, Persian and Russian, but the original roots lay in the very heart of the Turkic people. Hence, language is the soul of a nation and a history of constant movement. Its past and present are expressed in language. The most important witness to the survival of the nation is language. 


\section{REFERENCES}

1. Abdulakhat Kakhkharov. Yusuf Khos Khojib is a great thinker of the Turkic world. Tashkent: Navro'z, 2016 .p.156.

2. Adib Ahmad Yugnakiy. Hibatu-lhaqayiq. In the transcription, interpretation and analysis of Kasimjon Sodiqov. Tashkent: Akademnashr, 2019. - p. 168.

3. Alisher Navoi. Muhokamatu-llug'atayn. Under the analysis and interpretation of Kasimjon Sodiqov. Tashkent: Akademnashr, 2017. - p. 128.

4. Muhammad Rizobek Khokisor. Dictionary of Alisher Navoi's works. Tashkent: Akademnashr, 2017. - p. 416.

5. Mahmud Kashgari. Office of Turkish Words. (Dīwān Lughāt al-Turk). Translator and publisher: Salih Mutallibov. Tashkent: Fan, 1963.

6. Nasrullaev Ne'matullo. Theoretical problems of codicology and textology. Tashkent: "Music" publishing house, 2019. - p. 134.

7. Nasrullaev Ne'matullo. Source Studies (Textbook). Tashkent: Akademnashr, 2020. - p. 443.

8. Rashid Zohid. Problems of complex study of the text, commentaries and scientific critical text of Sabotul Ojizin's work. Tashkent: "Turon zamin ziyo", 2015. - p. 264.

9. Rosenthal F. The triumph of knowledge. Moscow: "Science", 1978. - p. 372.

10. Sadriddin Salim Bukhari. Dilda yor. Tashkent: Gafur Gulom Publishing House of Literature and Art, 1993. - p. 80.

11. da.m.wikipedia.org/wiki/Peter_Frederi k_Suhm. 